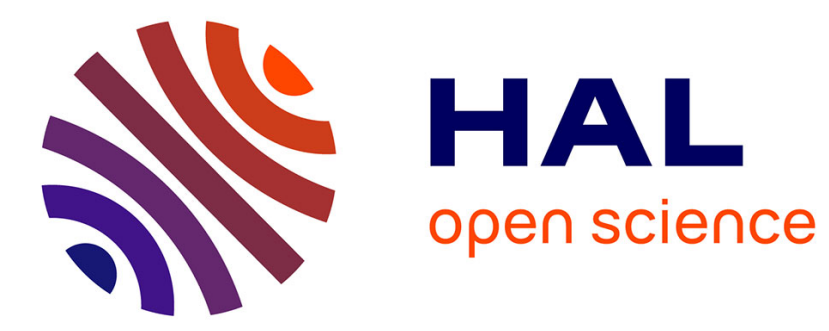

\title{
Limited interlaboratory comparison of Schmallenberg virus antibody detection in serum samples
}

W.H.M. van Der Poel, Brigitte Cay, Stéphan Zientara, F. Steinbach, Jean Francois Valarcher, Anette Bøtner, M.H Mars, R. Hakze-van Der Honing, H. Schirrmeier, M. Beer

\section{To cite this version:}

W.H.M. van Der Poel, Brigitte Cay, Stéphan Zientara, F. Steinbach, Jean Francois Valarcher, et al.. Limited interlaboratory comparison of Schmallenberg virus antibody detection in serum samples. Veterinary Record, 2014, 174 (15), 10.1136/vr.102180 . hal-01223536

\section{HAL Id: hal-01223536 https://hal.science/hal-01223536}

Submitted on 28 Nov 2015

HAL is a multi-disciplinary open access archive for the deposit and dissemination of scientific research documents, whether they are published or not. The documents may come from teaching and research institutions in France or abroad, or from public or private research centers.
L'archive ouverte pluridisciplinaire HAL, est destinée au dépôt et à la diffusion de documents scientifiques de niveau recherche, publiés ou non, émanant des établissements d'enseignement et de recherche français ou étrangers, des laboratoires publics ou privés. 


\title{
Paper
}

\section{Limited interlaboratory comparison of Schmallenberg virus antibody detection in serum samples}

\author{
W. H. M. van der Poel, B. Cay, S. Zientara, F. Steinbach, J. F. Valarcher, A. Bøtner, M. H. Mars, \\ R. Hakze-van der Honing, H. Schirrmeier, M. Beer
}

\begin{abstract}
Eight veterinary institutes in seven different countries in Europe participated in a limited interlaboratory comparison trial to evaluate laboratory performances of Schmallenberg virus (SBV) antibody detection in serum. Seven different sheep sera and three different cattle sera were circulated, and all participating institutes were asked to test these sera using SBV antibody detection assay(s) in place in their laboratories. All laboratories within the trial performed a virus neutralisation test (VNT) as well as one or two ELISAs on all samples, and swiftly detected SBV antibodies using these assays. VNT was more sensitive in detecting SBV antibodies than several of the used ELISA assays. Based on the test results, one cattle and one sheep SBV antibody-positive serum were selected to serve as reference sera, which now can be supplied to other laboratories on request.
\end{abstract}

\begin{abstract}
Introduction
Schmallenberg virus (SBV) was discovered in November 2011, and named after the village in Germany where it was first detected in blood samples from a dairy herd. Acute SBV infections presented with fever and reduced milk yield in dairy cattle (Hoffmann and others 2012, Muskens and others 2012). From December 2011 onward, the SBV outbreak resulted in a rapid increase of malformations in newborn lambs and calves (Van den Brom and others 2012), first in the European Union and later on also in the surrounding countries (EFSA 2012). Very soon after the SBV outbreak started, veterinary institutes in the affected countries worked together on the development of diagnostic tools, including antibody detection tests which were indispensable for the needed epidemiological surveys. Laboratories first implemented virus neutralisation tests (VNT) whereas primary focus of the industry was on the development of SBV ELISAs. In order to obtain a first impression of laboratory performances in SBV antibody
\end{abstract}

\section{Veterinary Record (2014)}

W. H. M. van der Poel, PhD, DVM R. Hakze-van der Honing, Central Veterinary Institute of Wageningen UR (CVI), The Netherlands B. Cay, PhD, DVM

Veterinary and Agrochemical Research Centre (VAR-CODA), Belgium

S. Zientara, PhD, DVM

Agency for Food, Environmental and

Occupational Health \& Safety (ANSES), France

F. Steinbach, PhD, MRCVS

Dept. of Virology, Animal Health

and Veterinary Laboratories Agency

(AHVLA), UK

J. F. Valarcher, PhD, DVM

National Veterinary Institute (SVA),

Sweden

doi: 10.1136/vr.102180

\author{
A. Botner, PhD, DVM \\ National Veterinary Institute (DTU-VET), \\ Denmark \\ M. H. Mars, PhD, DVM \\ Animal Health Service (GD), The \\ Netherlands \\ H. Schirrmeier, \\ M. Beer, PhD, DVM \\ Friedrich Loeffler Institut (FLI), \\ Germany
}

E-mail for correspondence:

wim.vanderpoel@wur.nl

Provenance: not commissioned; externally peer reviewed

Accepted February 3, 2014 testing in Europe a simple straightforward interlaboratory ring trial was organised in June 2012.

\section{Materials and methods \\ Samples}

Seven sheep sera were selected by the Central Veterinary Institute (CVI) in The Netherlands. Three of these sera were previously tested negative, and four of these sera were tested positive (various antibody levels) by VNT at CVI. The set included two convalescent samples of two different sheep (four specimens), obtained from a sheep infection experiment performed at CVI. The remaining three sera were obtained from adult sheep naturally infected in the field in September 2011. Three different cattle sera were selected by the Friedrich Loeffler Institut (FLI) in Germany. Two of these had previously been tested positive (different antibody levels) and one was tested negative by VNT at FLI. The cattle sera were obtained from an experimental infection experiment performed at FLI, in 2012 (Hoffmann and others 2011).

\section{Participating institutes}

Eight veterinary institutes from seven different countries participated in the SBV antibody detection ring trial. The following institutes were involved (alphabetical order): Agency for Food, Environmental and Occupational Health \& Safety (ANSES), France; Animal Health and Veterinary Laboratories Agency (AHVLA), UK; Animal Health Service (GD), The Netherlands; Central Veterinary Institute of Wageningen UR (CVI), The Netherlands; FLI, Germany; National Veterinary Institute (DTU-VET), Denmark; National Veterinary Institute (SVA), Sweden; Veterinary and Agrochemical Research Centre (VAR-CODA), Belgium.

\section{Assays}

Totally, the eight laboratories in the trial used six different SBV antibody detection assays. Besides the VNTs, three laboratories performed an in-house ELISA and six laboratories used one or more commercially available ELISAs. The VNTs carried out were not identical in procedure. For example, in one protocol, a higher amount of infectious virus (500TCID50 instead of 100TCID50) was used and one 


\begin{tabular}{|c|c|c|c|c|c|c|c|c|}
\hline \multirow[b]{2}{*}{ Serum } & \multicolumn{8}{|c|}{ Laboratory } \\
\hline & A & B & C & D & $E$ & $\mathrm{~F}$ & G & H \\
\hline 6513 & 64 & 128 & 96 & 128 & 64 & 30 & 128 & 40 \\
\hline 6514 & $<4$ & $<2$ & $<4$ & 2 & $<4$ & $<5$ & 4 & Neg \\
\hline 6516 & 48 & 128 & 96 & 32 & 32 & 30 & 48 & 40 \\
\hline $107 \mathrm{~A}$ & 192 & 512 & 32 & 64 & $32-64$ & 30 & 512 & 40 \\
\hline 107B & 192 & 256 & 384 & 128 & 64 & 60 & 64 & 80 \\
\hline $107 C$ & $<4$ & $<2$ & $<4$ & Neg & $<4$ & $<5$ & $<4$ & Neg \\
\hline 107D & $<4$ & $<2$ & $<4$ & Neg & $<4$ & $<5$ & $<4$ & Neg \\
\hline R1 & $\geq 512$ & 512 & 1536 & 64 & $\geq 256$ & 320 & 96 & 640 \\
\hline R2 & 192 & 128 & 128 & 16 & $32-64$ & 60 & 24 & 80 \\
\hline R3 & $<4$ & $<2$ & $<4$ & Neg & $<4$ & $<5$ & $<4$ & Neg \\
\hline
\end{tabular}

Results were copied as reported by the laboratory. Titres $\leq 4$ were considered SBV antibody negative (bold fields) (for additional information see Materials and Methods)

laboratory used BHK-21 cells while all others used Vero cells. In addition there were differences in readout (different percentages of destruction/inhibition per well). (Loeffen and others 2012; Mansfield and others 2013). For two laboratories, the in-house ELISA was developed in a collaborative study (Van der Heijden and others 2013). The commercially available assays included three different products supplied by ID-VET, IDEXX or LSI, respectively. The commercially available assays were always performed according to the manufacturers' instructions. For each assay, all participants were asked to perform an antibody titration or determine S/P values (optical density (OD) sample/OD positive control) in accordance with routine procedures in the laboratory and in accordance with manufacturers' instruction as appropriate. All results were reported to the organising laboratory and copied into tables (Tables 1 and 2).

\section{Results}

Virus neutralisation titres are listed in Table 1. Results were in agreement for all participants. All laboratories detected SBV antibodies in the same four sheep sera $(6513,6516,107 \mathrm{~A}$ and 107B) and did not detect SBV-specific antibodies in the remaining three sheep sera (6514, 107C and 107D). One cattle serum was tested SBV antibody negative by VNT (R3), and two (R1 and R2) were tested positive by all participating laboratories (Table 1).

ELISA titres are listed in Table 2. ELISA assays within all participating laboratories performed well. For three out of four ELISA formats there was a complete agreement between laboratories regarding the seronegative results in sheep sera as well as in bovine sera. Of two sheep samples, the result had to be designated as 'doubtful' by two laboratories, whereas these samples were mainly scored positive by other labs (6-8 lab/test combinations) (Table 2).

If 'doubtful' ELISA results were considered positive, a higher degree of agreement between ELISAs and VNT would be reached.

\section{Discussion}

To obtain a first impression of laboratory performances of SBV antibody testing in Europe, a simple and straightforward interlaboratory ring trial was organised in June 2012. Eight veterinary institutes in seven different countries tested a series of seven sheep serum samples and three bovine serum samples, using VNT and ELISA. VNT results of all samples were in agreement between laboratories. ELISA results were in agreement between laboratories apart from one sheep sample and one bovine sample which were reported to be 'doubtful' in four and three laboratories, respectively.

This study gives a good impression of routine SBV serology in European veterinary laboratories, and the results are promising for VNTs as well as for ELISAs. The study was not an evaluation of the sensitivities of the different assays and it did not include an evaluation of the cut-off values of the used assays. Although not one consistent protocol was applied, VNT results were in agreement between laboratories. For ELISA results there were some discrepancies, partly because certain $\mathrm{S} / \mathrm{P}$ ranges have been indicated as 'doubtful' by the ELISA manufacturers. The 'doubtful' results were $\mathrm{S} / \mathrm{P}$ values (OD sample/ $\mathrm{OD}$-positive control) $<10$ per cent under the cut-off value for a positive result. If all the 'doubtful' ELISA test results were to be considered antibody positive, more ELISA results would have been in agreement with VNT results. This raises the question whether the cut-off value of the involved assays could be lowered. However, a more extensive validation of the involved assays will be needed to answer this question.

This study gives an impression of the sensitivity and the specificity of SBV antibody detection assays in different laboratories, but it has to be taken into account that a very limited number of samples were tested in this trial. To assess sensitivity and specificity of ELISAs, a much larger and more varied set of samples will have to be tested. In such a study, a common VNT protocol could serve as standard. To evaluate repeatability, reproducibility and robustness of the assays, repeated testing within laboratories will be needed.

It can be concluded that SBV antibody detection in the different veterinary laboratories within European Union (EU) is reliable. Validation work of some of the used assays in this study has been published elsewhere (Breard and others 2013, Mansfield and others 2013 Van der Heijden and others 2013), and further validation of in-house as well as commercially available ELISAs in the field is on-going. SBV antibody positive sheep and bovine reference sera have been made available and can help to continue assessment of SBV antibody detection performances in laboratories in $\mathrm{EU}$ and countries outside EU. For such purpose, sheep serum 6513 can be supplied by CVI, and bovine serum R1 can be supplied by FLI. If needed, SBV positive sera can be accompanied with certified SBV antibody negative sera.

TABLE 2: Schmallenberg virus (SBV) specific antibody detection ELISA S/P values in seven different sheep sera $(6613,6514$ $6516,107 A, 107 B, 107 C$ and 107D) and three different cattle sera (R1, R2, R3) by ELISAs (formats $\alpha, \beta, \gamma, \delta$ ) performed in eight different veterinary laboratories $(\mathrm{A}-\mathrm{H})$

\begin{tabular}{|c|c|c|c|c|c|c|c|c|c|c|c|}
\hline \multirow[b]{2}{*}{ Serum } & \multicolumn{11}{|c|}{ Laboratory (Elisa format) } \\
\hline & $A(\delta)$ & $B(\alpha)$ & $C(\alpha)$ & $D(\alpha)$ & $E(\alpha)$ & $F(\alpha)$ & $\mathrm{G}(\delta)$ & $H(\alpha)$ & $D(\beta)$ & $\mathrm{E}(\gamma)$ & $F(\beta)$ \\
\hline 6513 & 73 & 219 & 100 & 74 & 172 & 103 & 116 & 89.6 & 55 & 81 & 65 \\
\hline 6514 & 7 & 37 & 26 & 12 & 23 & 19 & 11 & 10.9 & 13 & -1 & 9 \\
\hline 6516 & 65 & 152 & 94 & 77 & 170 & 110 & 105 & $>100$ & 59 & 80 & 77 \\
\hline $107 \mathrm{~A}$ & 12 & 180 & 73 & $\underline{53}$ & 47 & 40 & 25 & 35.7 & $\underline{35}$ & 20 & 40 \\
\hline 107B & 60 & 237 & 105 & $\overline{79}$ & 108 & 99 & 70 & 83.2 & $\overline{59}$ & 35 & 68 \\
\hline $107 C$ & -1 & 4 & 1 & 0 & -6 & 4 & -1 & 0.1 & -4 & -2 & -7 \\
\hline 107D & -1 & 1 & 1 & 1 & -10 & 6 & -3 & 0 & -4 & -2 & -7 \\
\hline R1 & 134 & 245 & 108 & 138 & 271 & 87.6 & 158 & $>100$ & 88 & 145 & 104 \\
\hline R2 & 94 & 155 & 90 & 50 & 120 & $\underline{56}$ & 116 & $\underline{52.8}$ & 76 & 67 & 45 \\
\hline R3 & 7 & 4 & 1 & 0 & 5 & $\overline{2}$ & -3 & $\overline{0}$ & -2 & -3 & -6 \\
\hline
\end{tabular}

Tests were performed according manufacturers' instructions. S/P values (OD sample/OD positive control) were copied as reported by the laboratory. Values in bold were considered SBV antibody positive using the cut-off values of the manufacturers' instructions (underlined text: doubtful) (for additional information see Materials and Methods) 


\section{Acknowledgements}

We wish to thank Betty Verstraten en Els de Boer-Luijtze, CVI, Bianka Hillmann, FLI, Blomqvist Gunilla, Katarina Näslund; and Caroline Vernersson, SVA, Corinne Sailleau and Cyril Viarouge and Emmanuel Bréard, ANSES, Anna La Rocca, Siva Karunakaran, Meenakshi Khatri, and Julie Peake, AHVLA for technical assistance. This study was commissioned by European Commission and the national governments of Belgium, France, Germany, The Netherlands and UK, implementing decision of 27 June 2012 concerning a financial contribution for studies on Schmallenberg virus. Commissioners had no involvement in the study design, collection, analysis or interpretation of the data of this study.

\section{References}

BREARD, E., LARA, E., COMTET, L., VIAROUGE, C., DOCEUL, V., DESPRAT, A., VITOUR, D., POZZI, N., CAY, A. B., DE REGGE, N., POUROUIER, P., SCHIRRMEIER, H., HOFFMANN, B., BEER, M., SAILLEAU, C. \& ZIENTARA, S (2013) Validation of a commercially available indirect EISA using a nucleocapsid recombinant protein for detection of Schmallenberg virus antibodies. PLoS One 8 , e53446

EFSA, EUROPEAN FOOD SAFETY AUTHORITY. “'Schmallenberg” virus: Analysis of the Epidemiological Data and Assessment of Impact. Scientific report, June 2012 HOFFMANN, B., SCHEUCH, M., HöPER, D., JUNGBLUT, R., HOLSTEG, M., SCHIRRMEIER, H., ESCHBAUMER, M., GOLLER, K. V., WERNIKE, K.,
FISCHER, M., BREITHAUPT, A., METTENLEITER, T. C. \& BEER, M. (2012) Novel orthobunyavirus in Cattle, Europe. Emerging Infectious Diseases 18, 469-472

LOEFFEN, W. L. F., OUAK, S., DE BOER-LUIJTZE, E., VAN DER POEL, W. H. M BOUWSTRA, R. J. \& MAAS, R. (2012) Development of a virus neutralisation test to detect antibodies against Schmallenberg virus and first results in suspect and infected herds. Acta Veterinaria Scandinavica 54, 44

MANSFIELD, K. L., LA ROCCA, S. A., KHATRI, M., JOHNSON, N., STEINBACH, F, FOOKS, A.R. (2013). Detection of Schmallenberg virus serum neutralising antibodies. J Virol Methods, 188, 139-144

MUSKENS, J., SMOLENAARS, A. J., VAN DER POEL, W. H., MARS, M. H., VAN WUIJCKHUISE, L., HOLZHAUER, M., VAN WEERING, H. \& KOCK, P. (2012) Diarrhea and loss of production on Dutch dairy farms caused by the Schmallenberg virus. Tijdschrift Voor Diergeneeskunde 137, 112-115

VAN DEN BROM, R., LUTTIKHOLT, S. J., LIEVAART-PETERSON, K., PEPERKAMP N. H., MARS, M. H., VAN DER POEL, W. H. M. \& VELLEMA, P. (2012) Epizootic of ovine congenital malformations associated with Schmallenberg virus infection. Tijdschr Diergeneeskd;137:106-111

VAN DER HEIJDEN, H. M. J. F, BOUWSTRA, R. J., MARS, M.H., VAN DER POEL W. H. M., WELLENBERG, G. J. \& VAN MAANEN, C. (2013) Development and validation of an indirect Enzyme-linked Immunosorbent Assay for the detection of antibodies against Schmallenberg virus in blood samples from ruminants. Research in Veterinary Science 95, 731-5 


\section{Veterinary Limited interlaboratory comparison of Record Schmallenberg virus antibody detection in serum samples}

W. H. M. van der Poel, B. Cay, S. Zientara, et al.

Veterinary Record 2014 174: 380 originally published online March 3, 2014

doi: $10.1136 / v r .102180$

Updated information and services can be found at:

http://veterinaryrecord.bmj.com/content/174/15/380.full.html

These include:

References This article cites 7 articles

http://veterinaryrecord.bmj.com/content/174/15/380.full.html\#ref-list-1

Email alerting Receive free email alerts when new articles cite this article. Sign up in service the box at the top right corner of the online article.

Notes

To request permissions go to:

http://group.bmj.com/group/rights-licensing/permissions

To order reprints go to:

http://journals.bmj.com/cgi/reprintform

To subscribe to BMJ go to:

http://group.bmj.com/subscribe/ 